Ann. Zootech., 1980, 29, no h. s., 99-118.

\title{
Variations of net requirements for cattle growth with liveweight, liveweight gain, breed and sex
}

\author{
J. ROBELIN" and R. DAENICKE*** \\ * Laboratoire de la Production de Viande, \\ Centre de Recherches de Clermont-Ferrand, I.N.R.A., \\ Theix, 63110 Beaumont (France), \\ **Institut für Tierernährung, \\ der Forschungsanstalt für Landwirtschaft, \\ Braunschweig-Völkenrode (Federal Republic of Germany),
}

\begin{abstract}
The main sources of variation in body and body gain composition of cattle - body weight, breed, sex, growth rate - are analysed in relation with the net requirements for growth.

There is a close relationship between proteins and fat free mass. Therefore, the variations in lipids will be emphasised.

- Variations with body weight : the lipid content of empty body weight gain rises very rapidly from 16 to 42 per cent with increasing empty body weight from 200 to $500 \mathrm{~kg}$ in early maturing bulls, fed almost ad libitum. Simultaneously the protein content of gain decreases from 19 to 14 per cent.

- Variations with breed : at the same empty body weight, say $350 \mathrm{~kg}$, the lipid content of empty body weight gain varies between breeds, from 15 per cent in late maturing breed bulls to 28 per cent in early maturing breed bulls.

- Variations with sex and castration : the percentage of lipids in the empty body weight gain of steers and heifers is 1.5 times as high as in bulls.

- Variations with growth rate : when the level of energy intake is increased, the daily lipid increases nearly twice as fast as the growth rate.

All these sources of variation are carefully analysed on the basis of a large number of data. This analysis leads to a model for evaluation of net requirements for cattle growth.
\end{abstract}

\section{Résumé}

Variations des besoins nets pour la croissance chez les bovins selon le poids vif, la vitesse de croissance, la race et le sexe

Les principales sources de variations de la composition corporelle et de la composition du croît des bovins - poids vif, vitesse de croissance, race, sexe - sont analysées en relation avec les besoins nets pour la croissance.

En raison de la relation étroite entre les protéines et la masse délipidée, on analysera surtout les variations concernant les lipides. 
- Variations avec le poids vif : la teneur en lipides du croît augmente très rapidement de 16 à 42 p. 100 chez les taurillons de race précoce, alimentés ad libitum entre 200 et $500 \mathrm{~kg}$. Simultanément, la teneur en protéines du crô̂t diminue de 19 à 14 p. 100.

- Variations selon la race : la teneur en lipides du croît varie selon la race des animaux, de 15 p. $100 \mathrm{chez}$ des taurillons de race tardive à 28 p. $100 \mathrm{chez}$ des taurillons de race précoce comparés à même poids vif vide $(350 \mathrm{~kg})$.

- Variations selon le sexe et avec la castration : la teneur en lipides du croît chez les boufs et les génisses est 1,5 fois plus élevée que chez les taurillons de même race et de même poids.

- Variations en fonction de la vitesse de croissance : lorsque le niveau des apports d'énergie est accru, la quantité de lipides fixée par jour s'accrôit approximativement deux fois plus rapidement que la vitesse de croissance.

Ces sources de variations sont analysées sur la base d'un grand nombre de résultats. Un modèle pour l'évaluation des besoins nets pour la croissance est proposé.

\section{Introduction}

The requirements of cattle for growth are closely related to the growth rate and the composition of body weight gain. For a very long time, studies on whole body composition of cattle were done only with very early maturing animals such as Hereford or Angus steers and heifers (Moulton et al., 1922 ; CALlow, 1947 ; LOFGreEN and GarRetT, 1968). Their results were therefore not suitable for other types of cattle and particularly for late maturing bulls grown in continental Europe. Data concerning the body composition of young bulls of various breeds have recently become available in publications. This paper intends to give a detailed analysis of the sources of variation in body composition of cattle such as body weight, growth rate, breed and sex ; the aim of this analysis was to propose a model for determining the net requirements for growth of cattle.

\section{I. - Interrelationships between chemical fractions of the body}

Body composition is a five component system of water, lipids, ash and proteins, but the variations of these fractions are closely interrelated.

Moulton (1923) showed that the fat free mass (FFM = empty body weight - lipids) had an almost constant composition in various species. We have recently shown (RoBELIN and GEAY, 1978) that the composition of fat free mass was not exactly constant, but was very highly correlated to the fat free mass itself, independent of animal breed and sex. Such a relationship has already been observed in normal and obese rats (BELL and STERN, 1977) and in birds (DELPECH, 1966).

This relationship has been re-analysed with more data (Table 1) including four types of animals : 1) very early maturing, Angus, Hereford or Shorthorn steers, called VEM steers in the text ; 2) early-maturing bulls (Friesian type) called EM bulls ; 3) late-maturing Charolais or Limousin bulls, called LM bulls ; 4) dual-purpose breed bulls (Simental, Salers...) intermediate between the two previous types, called IM bulls in the text. 
The weight of proteins is very highly correlated with the fat free mass. However, as shown in Figure 1, a slight difference between types of animals appears. Compared at the same fat free mass, the VEM steers had more proteins than Friesian or Limousin bulls and the latter had more proteins than Charolais bulls. This difference seems to be well related to the mature weight of animals, $700-800 \mathrm{~kg}$ for Angus or Hereford steers, $900-1000 \mathrm{~kg}$ for Friesian or Limousin bulls and $1100-1200 \mathrm{~kg}$ for Charolais bulls. As the percentage of proteins in the fat free mass increases with maturity, it is logical that with the same fat free mass, the animals that reached a greater percentage of mature weight have more proteins.

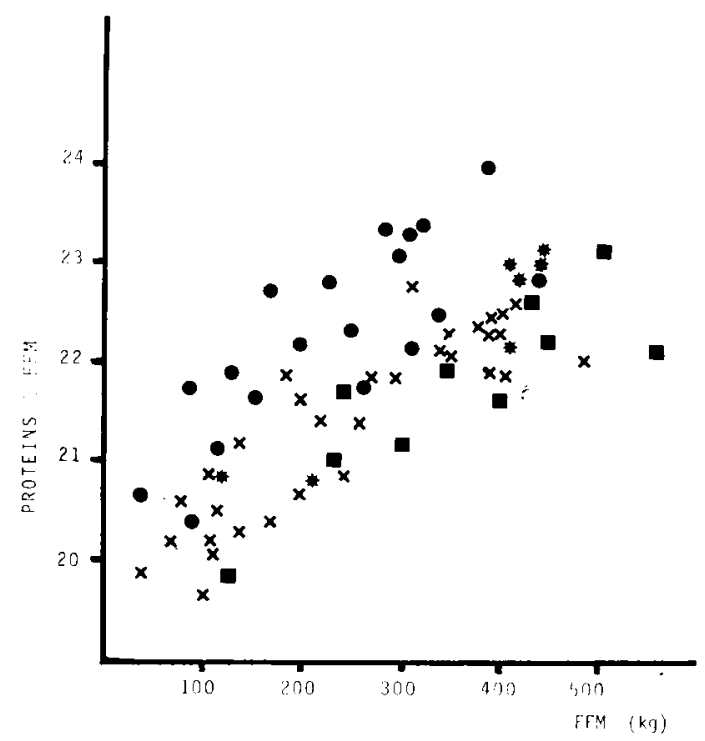

FIG. 1. - Variations of proteins percentage in fat free mass with fat free mass (FFM: $\mathrm{kg}=$ empty body weight - lipids) and types of animals: very early maturing steers (•), early maturing bulls $(\times)$, late maturing bulls $(\boldsymbol{*})$, and intermediate bulls $(*)$.

In fact, only the difference between Angus-Hereford steers and other animals is significant $(\mathrm{P}<0.01)$.

$\begin{array}{lll}\text { (eq. 1) } & \text { VEM Steers } & \text { Proteins }=0.1616 \mathrm{FFM}^{1.060} \\ \text { (eq. 2) } & \text { Bulls (all breeds) } & \text { Proteins }=0.1541 \mathrm{FFM}^{1.060} .\end{array}$

The residual coefficient of variation is equal to 2.8 per cent only. After mathematical derivation of these equations ( 1 and 2$)$, the daily protein retention (p) may be estimated from the empty body weight gain (EBWG) and the lipid deposition $(l)$.

(eq. 3) VEM Steers

(eq. 4) Bulls (all breeds) $\quad p=0.1633$ (EBWG $-l$ ) * FFM ${ }^{0.060}$.

From these equations, it is possible to show that $1 \mathrm{~g}$ of protein accretion in the body is accompanied by 3.1 to $2.8 \mathrm{~g}$ of water deposition, depending on FFM (200 to $500 \mathrm{~kg}$ ). These values come close to those observed by VAN Es 


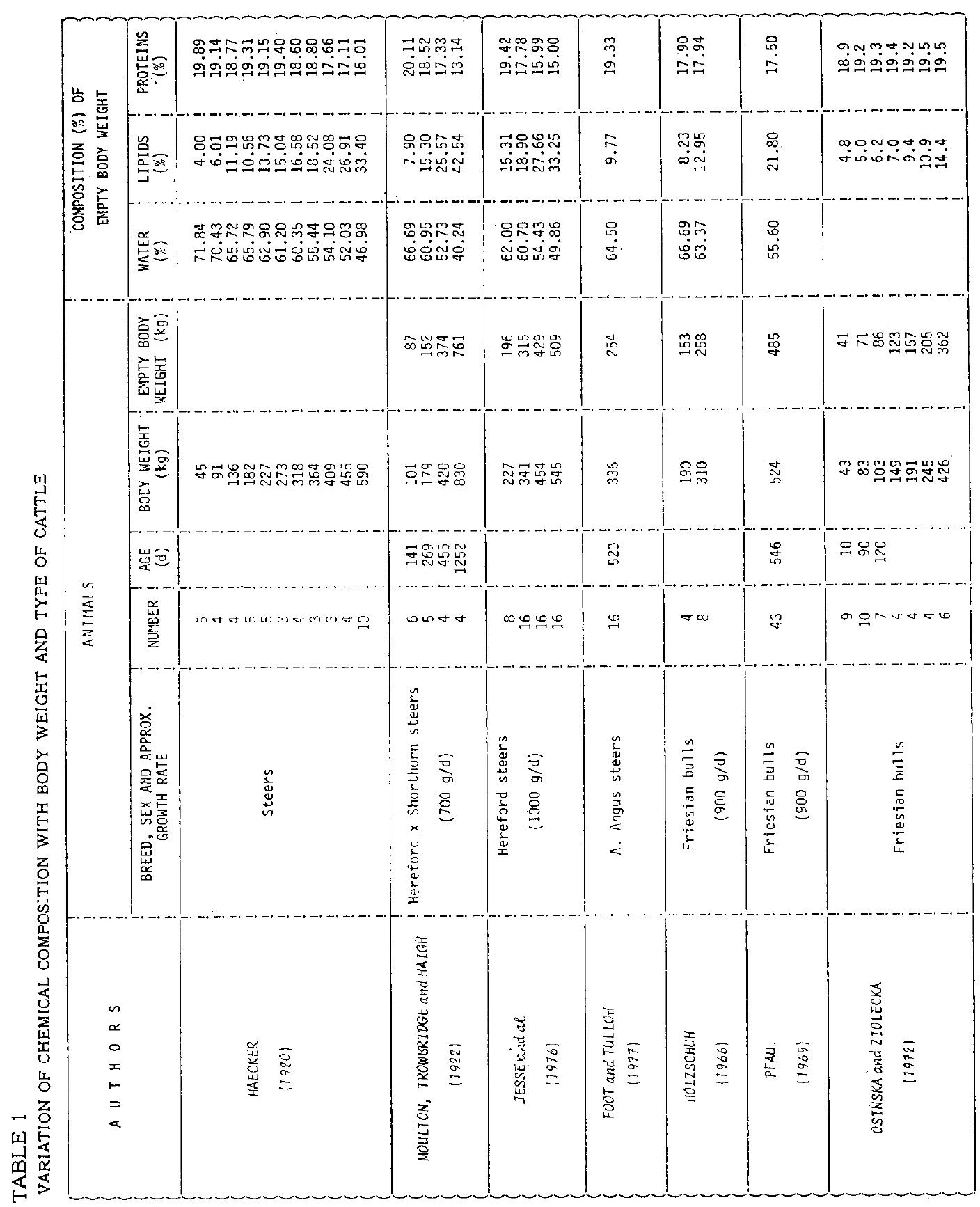




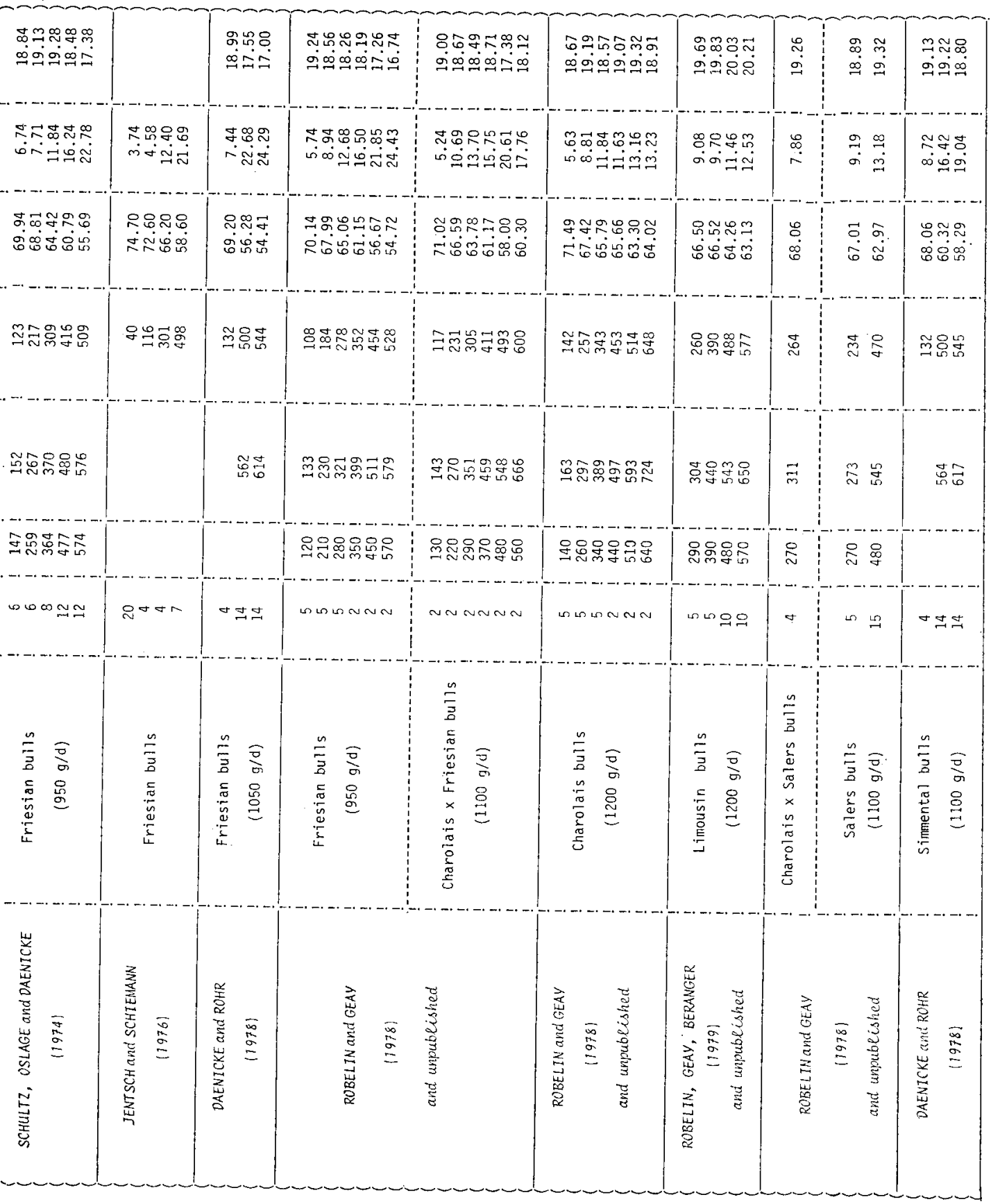


(1976). They show that on a net energy basis, the deposition of $1 \mathrm{~g}$ of fat $(9.4 \mathrm{kcal})$ is approximately 7 times more expensive than the deposition of $1 \mathrm{~g}$ of fat free mass.

\section{II. - Variation of body composition with body weight and breed}

As the weight of body proteins can be accurately estimated from the fat free mass, we have mainly focused the analysis on the variations of body lipids. The data presented in Figure 2 clearly show the degree to which the weight of

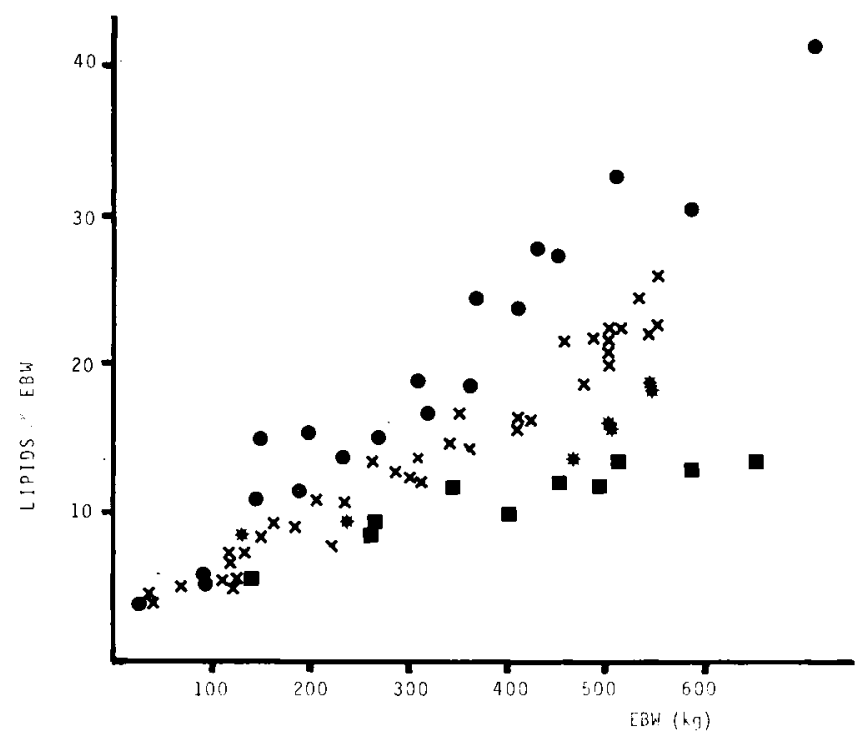

FIG. 2. - Variations of lipids percentage in empty body weight with empty body weight $(E B W ; \mathrm{kg})$ and types of animals : very early maturing steers $(\bullet)$, early maturing bulls $(\times)$, late maturing bulls ( $(-)$, and intermediate bulls (*).

lipids is really the most variable component of body composition. For the same empty body weight $(\mathrm{EBW}=400 \mathrm{~kg}$ ), it could vary from 11 per cent EBW in late maturing breed bulls, to 17 per cent EBW in early maturing breed bulls and 23 per cent EBW in very early maturing steers.

An extended allometric relationship was used for the analysis of the variations of lipid weight $(\mathrm{L} ; \mathrm{kg})$ with empty body weight $(\mathrm{EBW} ; \mathrm{kg})$.

(eq. 5) $\quad \log \mathrm{L}=b+b_{1} \log \mathrm{EBW}+b_{2}(\log \mathrm{EBW})^{2}$.

When the value of $b_{2}$ is not significantly different from zero, it means that the allometric coefficient of $\mathrm{L}$ remains constant $\left(b_{1}\right)$. On the contrary, it means that the allometric coefficient of $\mathrm{L}$ increases $\left(b_{2}>0\right)$ or decreases $\left(b_{2}<0\right)$ when the EBW increases (RoBeLIN et al., 1978). The following relationships were computed from the data listed in Table 1:

(eq. 6) VEM Steers: $\log \mathrm{L}=-6.311+1.81 \mathrm{Log} \mathrm{EBW} \mathrm{RCV}=21$ per cent. 
(eq. 7) EM Bulls: $\log \mathrm{L}=-1.680+0.0189 \log \mathrm{EBW}+$

$0.161(\log E B W)^{2} \mathrm{RCV}=13$ per cent.

(eq. 8) LM Bulls: $\log \mathrm{L}=-5.433+1.53 \log \mathrm{EBW} \mathrm{RCV}=9$ per cent.

The coefficient $b_{2}$ was only significant in equation 7 (early maturing bulls). It indicates an increase in the allometric coefficient of lipids from 1.50 to 2.02 between 100 and $500 \mathrm{~kg} \mathrm{EBW}$. The coefficient $b_{2}$ would probably have been significant in equation 6 (very early maturing steers) if the variability of the data had been lower. It was impossible to compare the value of the allometric coefficient derived from these three equations statistically, due to the quadratic form of equation 7 . However, the covariance analysis of the equations put in their linear form ( $b_{2}$ forced to zero) showed a highly significant difference between the slopes $b_{1}(1.81,1.71$ and 1.53 resp. for VEM steers, EM bulls and LM bulls) and between the adjusted weight of lipids for the mean EBW $=238 \mathrm{~kg}(36.4,27.1$ and $18.9 \mathrm{~kg}$ resp. for VEM steers, EM bulls and LM bulls).

The composition of empty body weight gain (EBWG) was estimated from the previous equations (see Appendix 1 and 2 for details of computations) and listed in Table 2.

As indicated by the allometric coefficient, the percentage of lipids in EBWG rises with higher EBW. Between 200 and $500 \mathrm{~kg}$ EBW, it increases from 16 per cent to 42 per cent in early maturing bulls. The lipid content of EBWG is lower

\section{TABLE 2}

ESTIMATED CHEMICAL COMPOSITION OF EMPTY BODY WEIGHT (EBW) AND OF EMPTY BODY WEIGHT GAIN (EBWG) OF CATTLE: VARIATIONS WITH BREED, SEX AND EMPTY BODY WEIGHT

\begin{tabular}{|c|c|c|c|c|c|c|c|c|}
\hline \multirow{3}{*}{$\begin{array}{l}\text { Chemical } \\
\text { components }\end{array}$} & \multirow{3}{*}{ Breed/sex $(1)$} & \multicolumn{6}{|c|}{ Empty body weight $(\mathrm{kg})$} & \multirow{2}{*}{$\begin{array}{l}\text { \% } \\
\text { \&BWG }\end{array}$} \\
\hline & & \multicolumn{2}{|c|}{200} & \multicolumn{3}{|c|}{350} & \multicolumn{2}{|c|}{500} \\
\hline & & \% EBW & 옿 EBWG & 응 $\mathrm{EBW}$ & 움 & EBWG & 8 EBW & \\
\hline Lipids & VEM steers & 13 & 24 & 21 & & 38 & 28 & 51 \\
\hline Lipids & EM bulls & 9 & 16 & 15 & & 28 & 21 & 42 \\
\hline Lipids & LM bulls & 7 & 11 & 10 & & 15 & 12 & 19 \\
\hline Proteins & VEM steers & 19 & 18 & 18 & & 15 & 16 & 12 \\
\hline Proteins & EM bulls & 19 & 19 & 18 & & 16 & 17 & 14 \\
\hline Proteins & LM bulls & 20 & 20 & 20 & & 19 & 19 & 19 \\
\hline Energy (2) & VEM steers & 2.3 & 3.2 & 2.9 & & 4.4 & 3.5 & 5.4 \\
\hline Energy (2) & EM bulls & 1.9 & 2.5 & 2.4 & & 3.6 & 2.9 & 4.7 \\
\hline Energy (2) & LM bulls & 1.8 & 2.2 & 2.0 & & 2.5 & 2.2 & 2.8 \\
\hline
\end{tabular}

(1) VEM steers = very early maturing steers (Hereford, Angus...)

EM bulls = early maturing bulls (Friesian type)

LM bulls = late maturing bulls (Charolais, Limousin)

(2) Energy is expressed in $\mathrm{Mcal} / \mathrm{kg}$ 
and increases more slowly in late maturing bulls (11 to 19 per cent) ; it is higher and increases more rapidly in very early maturing steers ( 24 to 51 per cent). Simultaneously, there is a decrease in the protein content of EBWG, but this evolution is very slow compared to the evolution of lipids (18 to 12 per cent, 19 to 14 per cent and 20 to 19 per cent resp. for VEM steers, EM bulls and LM bulls).

As a consequence of the higher heat value of lipids, the evolution of the caloric value of EBWG is quite similar to that of the lipid content of EBWG. Between 200 and $500 \mathrm{~kg} \mathrm{EBW}$ it increases from 3.2 to $5.4 \mathrm{Mcal} / \mathrm{kg}$ EBWG in VEM steers, from 2.5 to $4.7 \mathrm{Mcal} / \mathrm{kg} \mathrm{EBWG}$ in EM bulls and from 2.2 to $2.8 \mathrm{Mcal} / \mathrm{kg}$ EBWG in LM bulls.

The IM bulls were not included in this analysis, due to the small amount of data (Table 1). However, it can be seen from Figure 2 that, as far as lipid deposition is concerned, they could be considered intermediate between Friesian bulls and Charolais or Limousin bulls.

All these results have been obtained on animals fed almost ad libitum, with the daily gain of 0.7 to $1.2 \mathrm{~kg}$ /day depending on the type of animals (Table 1). They can be summarised by three main points : 1) the variations with empty body weight of protein content of empty body weight gain are very low except in very early maturing animals ; 2) the caloric value of gain increases approximately by 60 per cent between 200 and $500 \mathrm{~kg}$ empty body weight ; 3) for a given empty body weight the caloric value of gain varies approximately by 40 per cent between early and late maturing breed bulls. This difference is far greater when very early maturing steers are considered. However, it is difficult, up to this point in the analysis, to distinguish between the fraction due to the breed (Angus, Hereford vs Friesian or Charolais) and the fraction due to castration.

\section{III. - Variation of body composition with sex and castration}

A lot of work has been done over 20 years in order to quantify the differences between bulls, steers and heifers, in terms of growth rate, feed efficiency and body composition at slaughter (Review of TuRTON, 1969). A compilation of available results is presented in Tables 3 and 4 .

With the same diet, the average daily gain is nearly 16 per cent lower in steers than in bulls of the same breed, and 24 per cent lower in heifers than in bulls. At slaughter, the percentage of fatty tissue in the carcase is on average 37 per cent higher in steers than in bulls and 47 per cent higher in heifers than in bulls. These values are probably a good estimate of the true differences between these kinds of animals due to the large number of compiled results and to the relatively low range of variation between experiments. These differences obviously reflect large variations in the true needs of energy and proteins for growth, but there are no dynamic results in the bibliography actually comparing the composition of gain in bulls, steers, and heifers.

Faced with this lack of information, we have tried to estimate the composition of gain for these three types of animals from the data presented above (see details in Appendix 4). From these calculations, it appears that the percentage of lipids in empty body weight gain is nearly 54 per cent higher in steers than in bulls between castration and slaughter. This percentage is 51 per cent higher in heifers than in bulls between birth and slaughter. 


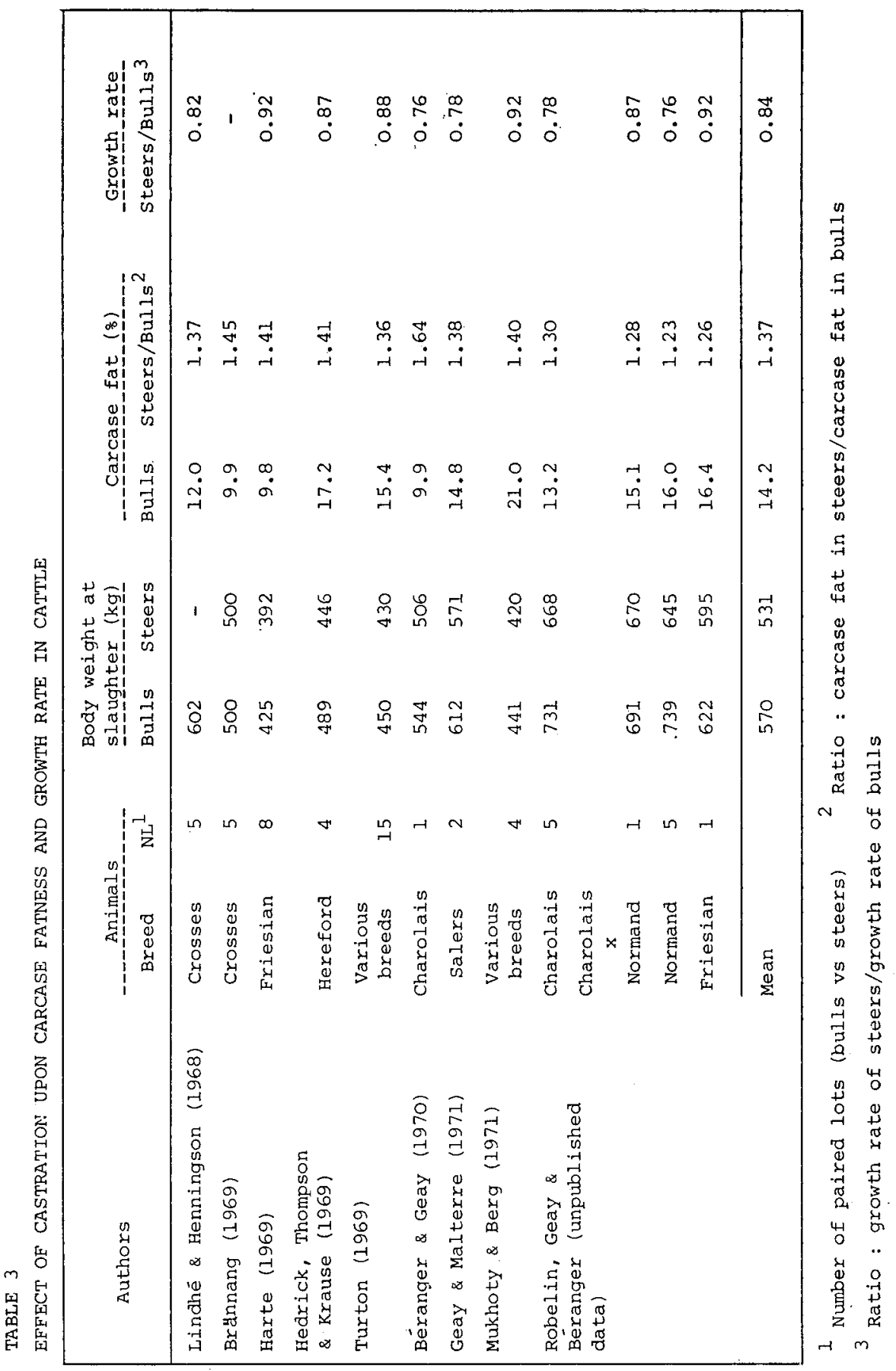




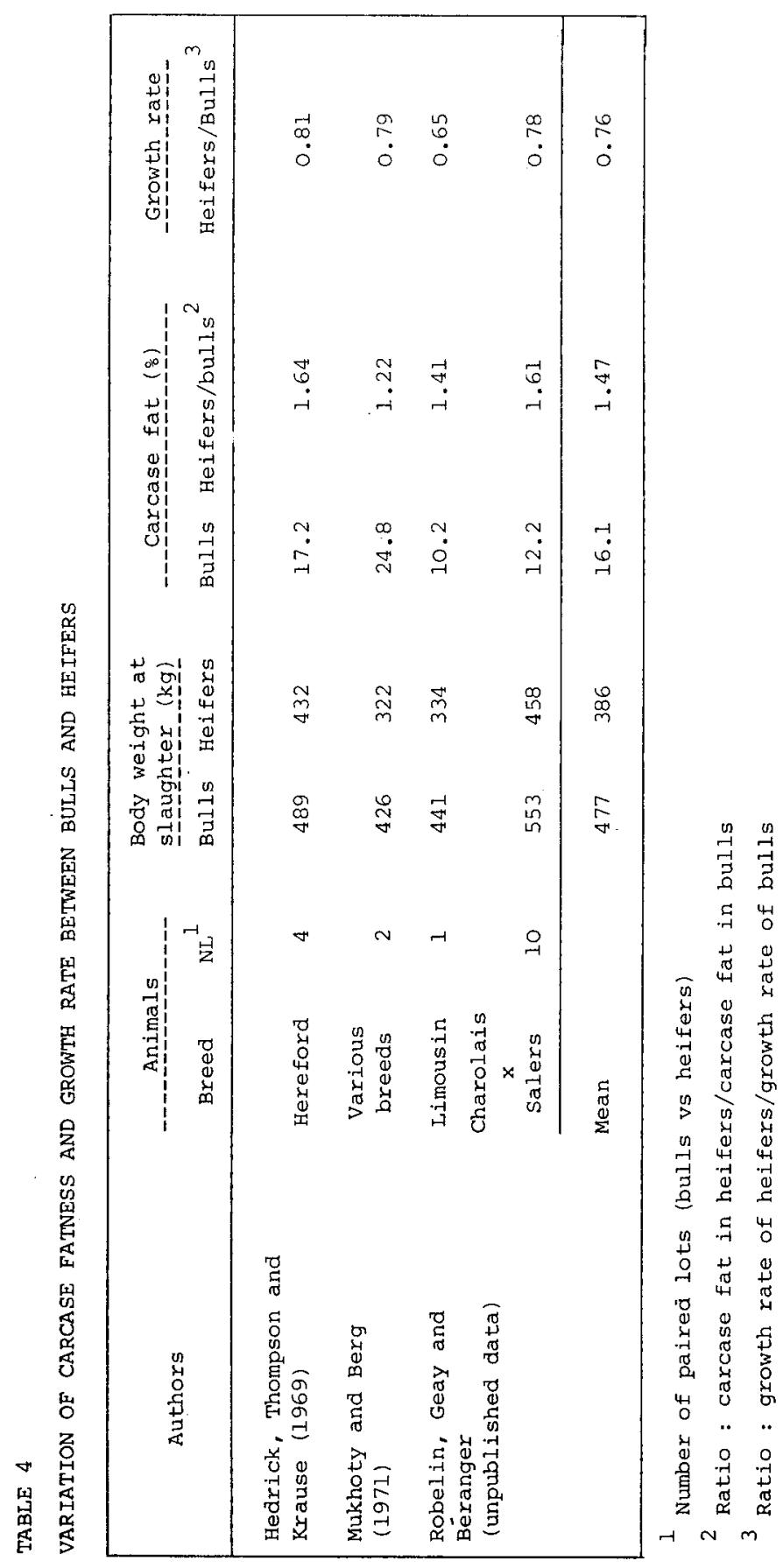


From this rough comparison, it can be said that, when bulls, steers, and heifers of the same breed are fed the same diet almost ad libitum during one fattening period, steers and heifers grow, respectively, 16 and 24 per cent less rapidly than bulls ; their percentage of lipids in the gain are similar and nearly 50 per cent higher than in bulls. As a consequence, the percentage of proteins in the empty body weight gain of steers and heifers is 10 per cent lower than in bulls, while the caloric value of gain is 28 per cent higher than in bulls.

\section{IV. - Variation of body composition with growth rate}

When the growth rate increases through higher energy intake, it is well known that the fatness of carcases at slaughter is increased. The results of 12 experiments summarised in Table 5 support this assertion. In these experiments involving two feeding levels the increase in energy intake induced an increase in growth rate by 38 per cent on the average (from 0.7 to $1.0 \mathrm{~kg} /$ day). It was accompanied by a 21 per cent increase in carcase fat (from 24 to 29 per cent fat) at the end of the experimental period. This is obviously due to an increase in the lipid content of the gain. Recently, we have analysed this relationship (ROBELIN, 1979) in Friesian and Charolais Salers bulls and in Charolais Salers heifers grown between 280 and $540 \mathrm{~kg}$ body weight. The mean body weight gain during this period varied between experimental lots from $627 \mathrm{~g} /$ day to $1450 \mathrm{~g} /$ day according to the energy supply. The daily lipid deposition ( $l ; \mathrm{kg} / \mathrm{day})$ was related to the empty body weight gain (EBWG ; $\mathrm{kg} /$ day according to the following model :

(eq. 9) $l=u \mathrm{EBWG}^{v}$.

The variations between breed and sex were estimated by covariance analysis. The value of the coefficient $u$, resp. $0.160,0.195,0.310$ for Charolais Salers bulls, Friesian bulls and Charolais Salers heifers, reflects the differences between types of animals in lipid deposition for the same EBWG $(1 \mathrm{~kg} / \mathrm{day})$. They are in agreement with the previous analysis.

The exponent $v$ was not significantly different between types of animals $(v=1.78)$. It means that when the daily gain increased by 10 per cent, the daily lipid deposition increased by 17.8 per cent. It should be noted that in absolute value ( $\mathrm{kg} /$ day), the increase of lipid deposition was much higher in the earlier maturing animals. For the same increase in daily weight gain from 1.0 to $1.2 \mathrm{~kg} / \mathrm{day}$, the lipid deposition increased by $0.12 \mathrm{~kg} /$ day (from 0.31 to 0.43 ) in Charolais Salers heifers, by $0.08 \mathrm{~kg} /$ day (from 0.19 to 0.27 ) in Friesian bulls and by $0.06 \mathrm{~kg} / \mathrm{day}$ (from 0.16 to 0.22 ) in Charolais Salers bulls.

The value of the exponent $v$ that we found (1.78) seems to be a good estimate of the variation of lipid deposition with feeding level. We estimated the daily lipid deposition in the experiments cited in Table 5 (see details in Appendix 5 ). The 38 per cent increase in growth rate due to the increase in energy intake, was accompanied by a 76 per cent increase in daily lipid deposition $(0.179$ to $0.316 \mathrm{~kg} /$ day). The estimated value of exponent $v$ was $\log .1 .76 / \log 1.38=1.76$.

Then, it could be concluded that when the feeding level of animals is increased, the daily lipid deposition increases nearly 1.8 times as fast as the daily empty body weight gain. 


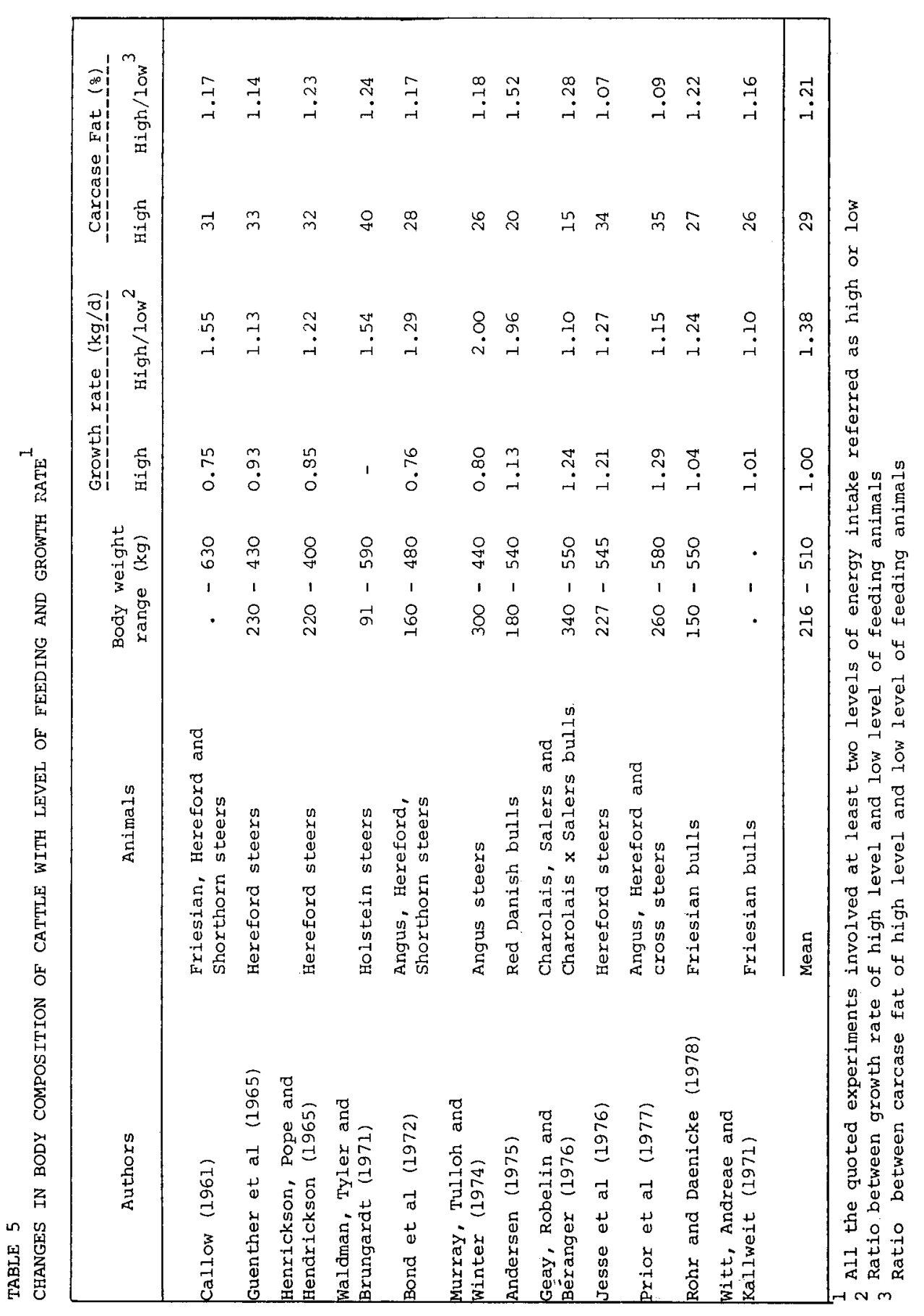




\section{V. - Model of estimation of energy and protein retained in growing cattle}

Three types of equations have been discussed until now (see Appendix 1) :

1) Body proteins $=a_{0} \mathrm{FFM}^{a 1}$.

2) Body lipids $=\operatorname{EXP}\left(b_{0}+b_{1} \log \mathrm{EBW}+b_{2}(\log \mathrm{EBW})^{2}\right)$.

3) Daily gain of lipids $=u \mathrm{EBWG}^{v}$.

From a nutritional point of view, only true needs for growth in terms of proteins and energy must be estimated. Energy can be calculated from proteins and lipids by the formula (RoBELIN and GEAY, 1976) :

Energy $(\mathrm{Mcal})=5.48$ Proteins $(\mathrm{kg})+9.37$ Lipids $(\mathrm{kg})$

The coefficients of this equation are in good agreement with those obtained by Paladines et al. (1964) or by FerRell et al. (1976).

From these relationships, it is possible to build an empirical model to estimate net requirements for growth according to body weight, body weight gain and types of animals. In order to simplify, we will consider only the example of Friesian bulls ; it could be easily extended to other kinds of animals provided the coefficients of equations are known. First of all body weight and body weight gain must be transformed into empty body weight and empty body weight gain through equation $\mathrm{E}$ (Appendix 1 and 2). Then for a given empty body weight $(\mathrm{EBW} ; \mathrm{kg}$ ) and a given empty body weight gain (EBWG ; $\mathrm{kg} /$ day), the daily retention of lipids ( $l$; $\mathrm{kg} /$ day) by Friesian bulls can be estimated with the following relationship (see details of calculation in Appendix 2 and 3):

$$
l=\frac{b \times \mathrm{L}}{\mathrm{EBW}} \mathrm{EBWG}^{1.78}
$$

where $b=0.0189+0.362 \log$ EBW:

$$
\mathrm{L}=\mathrm{EXP}\left(-1.680+0.0189 \log \mathrm{EBW}+0.1609(\log \mathrm{EBW})^{2}\right)
$$

The daily retention of proteins $(\mathrm{kg} / \mathrm{day})$ can be calculated with the following relationship:

$$
p=0.1633(\mathrm{EBWG}-l)(\mathrm{EBW}-\mathrm{L})^{0.06}
$$

The estimated value of $l, p$ and the corresponding value of energy retained have been listed in Table 6 .

This kind of calculation was used by GEAY et al. (1978) to calculate the net protein requirement for growth. The coefficients of equations used have been calculated from measurements of body composition by slaughter technique on various types of cattle.

The model derived from this analysis is only an empirical description of experimental results. Its accuracy within the range of data used (say, the range of EBW, EBWG and types of animals) is probably not questionable. However, some particular points have to be clarified. 1) It is necessary to know whether the relationship between empty body weight gain and lipid deposition can be extrapolated to a very low growth rate (lower than $0.5 \mathrm{~kg} /$ day). 2) This rela- 


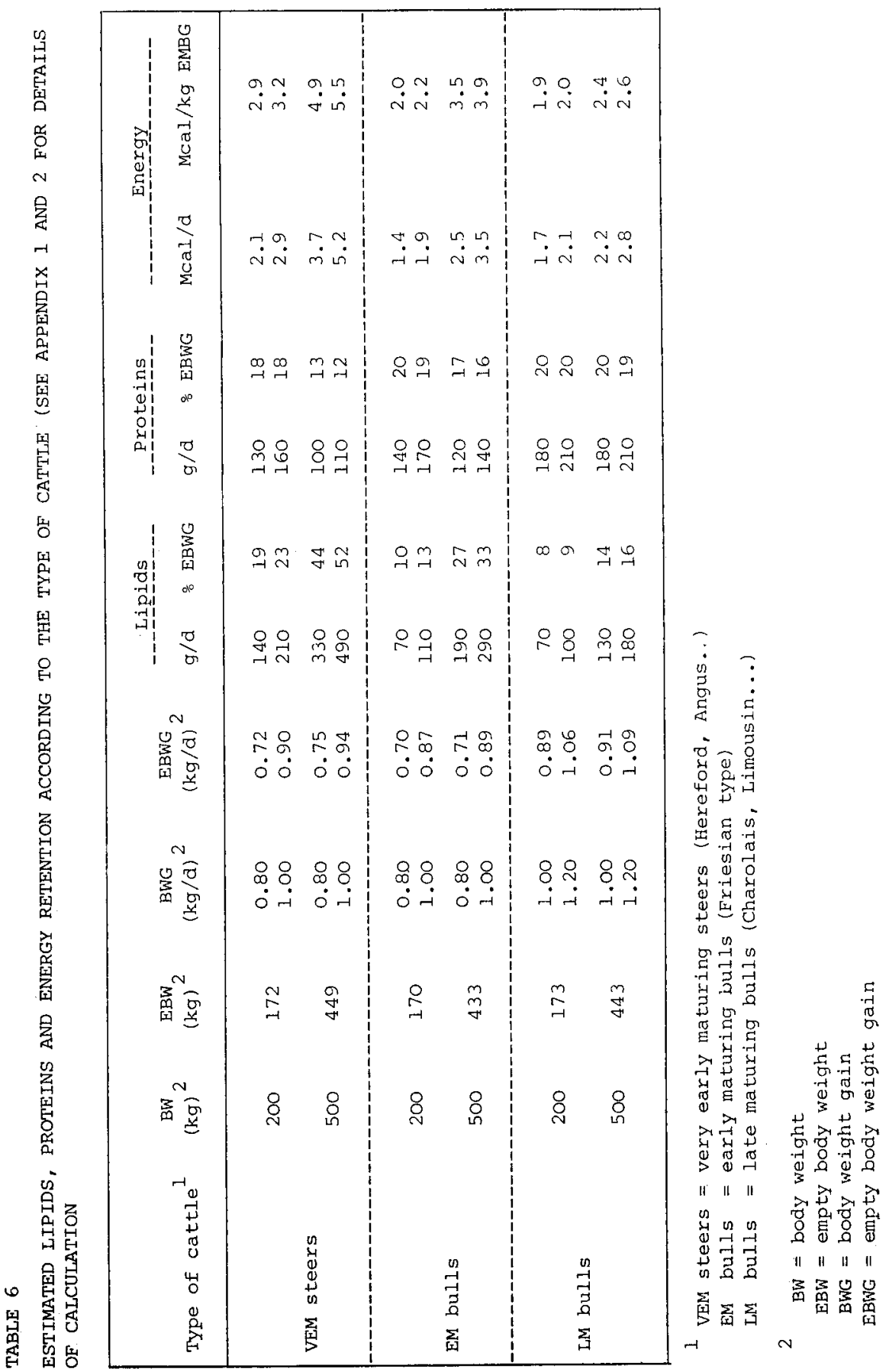


tionship may vary with body weight and maturity even if it does not seem to do so between animals varying in maturity. Experiments in progress may help to clear up this point. 3) The fact that the quadratic log-log relationship between the weight of lipids and empty body weight was only significant in Friesian bulls is not satisfactory. Is even the conventional allometric relationship really the best way? 4) In most cases, the sources of variation of body composition were analysed separately. The interactions between these factors now appear in need of analysis.

\section{Conclusion}

Large variations in the composition of body weight gain of cattle were observed. The most variable component was the lipid deposition while protein accretion appeared to follow fat free gain closely.

A model to calculate net requirements for growth has been proposed to give the general trends of variation in body gain composition according to several factors. Although this model still has to be improved and adapted to specific situations, it is quite certain that the patterns it shows are fairly good indications of actual trends, given the large number and the wide range of data analysed.

\section{References}

ANDERSEN H.R., 1975. The influence of slaughter weight and level of feeding on growth rate, feed conversion and carcass composition of bulls. Liv. Prod. Sci., 2, 341-355.

Bell G.E., Stern J.S., 1977. Evaluation of body composition of young obese and lean zucker rats. Growth, 41, 63-80.

Beranger C., Geay Y., 1970. Aptitudes des différentes catégories de jeunes bovins à la production de viande. Variations liées au sexe et au type génétique. In "La production de viande par les jeunes bovins". p. 81-94. Ed. S.E.I. Versailles.

Bond J., Hooven N.W., Warvick E.J., Hiner R.L., Richardson G.V., 1972. Influence of breed and plane of nutrition on performance of dairy, dual-purpose and beef steers. II From 180 days of age to slaughter. J. Anim. Sci., 34, 1046-1053.

BRÄNNANGE., 1969. The raising of bulls for beef in Sweden. In "Meat production from entire male animals". p. 173-178. Ed. D.N. Rhodes, J. and A. ChurchiLl Ltd London.

Callow E.H., 1947. Comparative studies of meat. I The chemical composition of fatty and muscular tissue in relation to growth and fattening. J. Agric. Sci., 37, 113-129.

Callow E.H., 1961. Comparative studies of meat. VII. A comparison between Hereford, dairy Shorthorn and Friesian steers on four levels of nutrition. J. Agric. Sci., 56, 265-281.

DAENICKE R., ROHR K., 1978. Influence of nutrition on body composition and carcass quality of fattening bulls of two different breeds (Friesian and Simmental). In "Patterns of growth and development in cattle", p. 423-434. DE BOER and MARTIN Ed. Martinus Nijhof, The Hague.

DelPeCh P., 1966. Le poids frais délipidé chez Gallus Gallus. C.R. Acad. Sci., 263, 1735-1738.

Foot J.Z., TUlLOH N.M., 1977. Effects of two paths of liveweight change on the efficiency of feed use and on body composition of Angus steers. J. Agric. Sci., 88, 135-142.

Ferrel C.L., Garrett W.N., Hinman N., 1976. Estimation of body composition in pregnant and non pregnant heifers. J. Anim. Sci., 42, 1158-1166.

Geay Y., Malterre C., 1971. Influence de la castration et de la nature des glucides de la ration sur la croissance et la qualité des carcasses de bovins abattus à 24 mois. Ann. Zootech., 20, 251-257.

Geay Y., Robelin J., Beranger C., 1976. Influence du niveau alimentaire sur le gain de poids vif et la composition de la carcasse de taurillons de différentes races. Ann. Zootech., $25,287-298$. 
Geay Y., Robelin J., Beranger C., Micol D., 1978. Besoins alimentaires des bovins en croissance et à l'engrais. In "Alimentation des Ruminants", p. 243-297. Ed. INRA - Publications Versailles.

Guenther J.J., Bushman D.H., Pope L.S., Morrison R.D., 1965. Growth and development of the major carcass tissues in beef calves from weaning to slaughter weight, with reference to the effect of plane of nutrition. J. Anim. Sci., 24, 1184-1191.

HaECKER T.L., 1920. Quoted by Berg R.T. and ButTERFIELD R.M., 1976. In "New concepts of cattle growth", p. 50 Sydney University Press.

HARTE F.J., 1969. Six years of bull beef production research in Ireland. In "Meat production from entire male animals", p. 153-171. Ed. D.N. Rhodes, J. and A. Churchill Ltd London.

Hedrick H.B., Thompson G.B., Krause G.F., 1969. Comparison of feedlot performance and carcass characteristics of half sib bulls, steers and heifers. J. Anim. Sci., 29, 687-694.

HenRickson R.L., POPE L.S., Hendrickson R.F., 1965. Effect of rate of gain of fattening beef calves on carcass composition. J. Anim. Sci., 24, 507-553.

HolzschuH W., 1966. Wachstum versuch verbunden mit Körperanalysen bei Jungmastbullen zur Ermittlung des N-ansatzes aus NPN-verbindungen. Arch. Tierzucht., 9, 159-176.

JentsCH W., SChIEMAN R., 1976. Die Verwertung der Futterenergie durch wachsenden Bullen. Arch. Tierernährg., 27, 545-562.

Jesse G.W., Thompson G.B., Clark J.L., Hedrick H.B., Weimer K.G., 1976. Effects of ration energy and slaughter weight on composition of empty body and carcass gain of beef cattle. J. Anim. Sci., 43, 418-425.

Lindhe B., Henningsson T., 1968. Crossbreeding for beef with Swedish Red and White cattle. II Growth and feed efficiency under standardised conditions together with detailed carcass evaluation. Lantbruckshögsk. Ann., 34, 517-549.

LOFGREEN G.P., GarReTt W.N., 1968. A system for expressing net energy requirements and feed values for growing and finishing beef cattle. J. Anim. Sci., 27, 793-806.

Moulton C.R., 1923. Age and chemical development in mammals. J. Biol. Chem., 57, 79-97.

Moulton C.R., Trowbridge P.F., Haigh L.D., 1922. Studies in animal nutrition. III Changes in chemical composition on different planes of nutrition. Mo. Agric. Exp. Stat. Bull., No. $55,1-87$.

Muknoty H., Berg R.T., 1971. Influence of breed and sex on the allometric growth patterns of major bovine tissues. Anim. Prod., 13, 219-227.

Murray D.M., Tulloh N.M., WInTER W.H., 1974. Effects of three different growth rates on empty body weight, carcass weight and dissected carcass composition of cattle. J. Agric. Sci., 82, 535-547.

Osinska Z., ZIOLECKA A., 1972. A note on the protein content of the empty body of young Polish Black and White Lowland Bulls. Anim. Prod., 14, 119-122.

Paladines O.L., Reid J.T., Bensadoun A., Van Niekerk B.D.H., 1964. Heat combustion value of protein and fat in the body and wool of sheep. J. Nutr., 82, 145-149.

Pfau A., 1969. Statistish abgeleitete Relationen zur Bestimmung der grosschemischen Körperzusammensetzung beim Rind. Z. Tierzucht., 85, 363-369.

Prior R.L., Kohlmeier R.H., Cundiff L.V., Dikeman M.E., Crouse J.D., $1977 . \quad$ Influence of dietary energy and protein on growth and carcass composition in different biological types of cattle. J. Anim. Sci., 45, 132-146.

RoBELIN J., 1979. Influence de la vitesse de croissance sur la composition du gain de poids des bovins : Variations selon la race et le sexe. Ann. Zootech., 28, 209-218.

Robelin J., Geay Y., 1976. Estimation de la composition des carcasses de jeunes bovins à partir de la composition d'un morceau monocostal prélevé au niveau de la $11^{\mathrm{e}}$ cote. II Composition chimique de la carcasse. Ann. Zootech., 25, 259-272.

Robelin J., Geay Y., 1978. Estimation de la composition chimique du corps entier des bovins à partir du poids des dépôts adipeux totaux. Ann. Zootech., 25, 159-167.

Robelin J., Geay Y., Beranger C., 1979. Evolution de la composition corporelle des jeunes bovins mâles entiers de race Limousine entre 9 et 19 mois. II Composition chimique et valeur calorifique. Ann. Zootech., 28, 191-208.

Rohr K., Daenicke R., 1978. Untersuchungen über dem Einfluss des Fütterungsniveau und der Energiekonzentration der Ration auf Pansenfermentation, Gewichtszuwachs und Schlachtkörperzusammensetzung Schwarzbunter Mastbullen. Züchtungskde, 50, 67-77.

Schultz E., Oslage H.J., Daenicke R., 1974. Untersuchungen über die Zusammensetzung der Körpersubstanz sowie den Stoff - und Energieansatz bei wachsenden Mastbullen. $Z$. Tierphys. Tierern. Futtermk., 4, 1-70. 
TURTON J.D., 1969. The effect of castration on meat production from cattle. In "Meat production from entire male animals", p. 1-50. Ed. D.N. RhODEs, J. and A. CHURCHILL Ltd London.

VAN Es A.J.H., 1976. Meat production from ruminants. Proc. Symposium on growth and productivity of meat animals, p. 341-401. Ed. LISTER D., RHODES D.N., FOWLER V.R., Fuller M.F., Plenum Press London.

Waldman R.C., Tyler W.J., Brungardt V.H., 1971. Changes of the carcass composition of Holstein steers associated with ration energy levels and growth. J. Anim. Sci., 32, 611-619.

WitT M., ANdres U., Kallweitr E., 1971. Einfluss unterschiedlicher Fütterungsintensität auf Wachstum und Fettansatz beim Rind, untersucht an eineigen Zwillingsbullen. Züchtungskunde, 43, 173-185.

\section{Appendix 1}

\section{Definitions and equations}

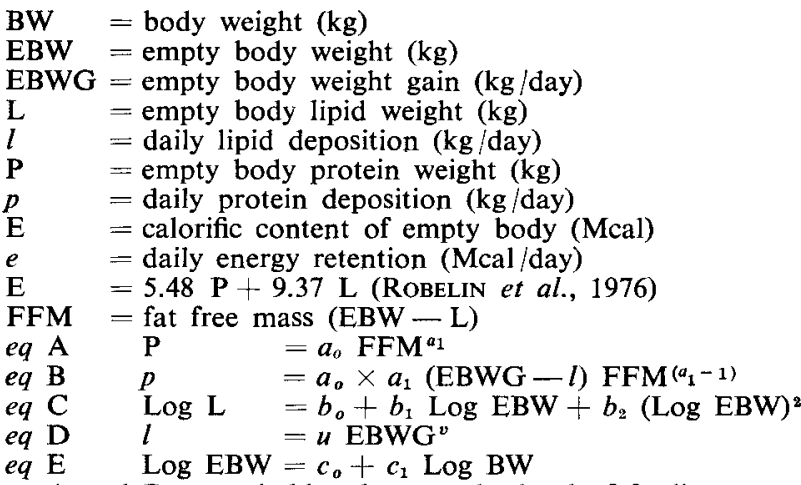

$e q \mathrm{~A}$ and $\mathrm{B}$ are suitable whatever the level of feeding

eq C computed from data presented in Table 1 is suitable for animals nearly fed ad libitum. The reference mean empty body weight gain $\left(\mathrm{EBWG}_{o}\right)$ was approximately $0.8 \mathrm{~kg} /$ day for very early maturing steers, $1.0 \mathrm{~kg} /$ day for early maturing bulls and $1.2 \mathrm{~kg} /$ day for the late maturing bulls.

ESTIMATED VALUES OF THE COEFFICIENTS

\begin{tabular}{lccccccccc}
\hline Types of animals & $a_{0}$ & $a_{1}$ & $b_{0}$ & $b_{1}$ & $h_{2}$ & $c_{0}$ & $c_{1}$ & $v$ \\
\hline $\begin{array}{l}\text { Very early matur- } \\
\text { ing steers }\end{array}$ & 0.1616 & 1.060 & -6.311 & 1.8110 & 0.000 & -0.3939 & 1.046 & 1.78 \\
$\begin{array}{l}\text { Early maturing } \\
\text { bulls }\end{array}$ & 0.1541 & 1.060 & -1.680 & 0.0189 & 0.1609 & -0.2855 & 1.023 & 1.78 \\
$\begin{array}{l}\text { Late maturing } \\
\text { bulls }\end{array}$ & 0.1541 & 1.060 & -5.433 & 1.5352 & 0.000 & -0.2704 & 1.024 & 1.78 \\
\hline
\end{tabular}




\section{Appendix 2}

Calculation of the body and body gain composition of animals growing with the reference empty body weight $\left(E B W G_{0}\right)$

Conversion of body weight and body weight gain into empty body weight and empty body weight gain.

From eq $\mathrm{E}$ (Appendix 1)

$$
\begin{aligned}
& \mathrm{EBW}=\mathrm{EXP}\left(c_{o}+c_{1} \log \mathrm{BW}\right) \\
& \mathrm{EBWG}=(\mathrm{EBW} / \mathrm{BW}) \times c_{1} \times \mathrm{BWG}
\end{aligned}
$$

Body components (L, P, E; $\mathrm{kg}$ and Mcal)

From eq $\mathrm{C}$ (Appendix 1)

$$
\begin{aligned}
& \mathrm{L}=\mathrm{EXP}\left(b_{o}+b_{1} \log \mathrm{EBW}+b_{2}(\log \mathrm{EBW})^{2}\right) \\
& \mathrm{FFM}=\mathrm{EBW}-\mathrm{L}
\end{aligned}
$$

From eq A (Appendix 1)

$$
\begin{aligned}
& \mathbf{P}=a_{0} F F M a_{1} \\
& \mathrm{E}=5.48 \mathbf{P}+9.37 \mathrm{~L}
\end{aligned}
$$

Daily retention of lipids, proteins and energy $(l, p . e ; \mathrm{kg} / \mathrm{day}$ and $\mathrm{Mcal} / \mathrm{day})$

By derivation of equation $\mathrm{C}$ (Appendix 1)

$$
\begin{aligned}
\frac{d \mathrm{~L}}{d \mathrm{EBW}} & =\frac{\mathrm{L}}{\mathrm{EBW}}\left(b_{1}+2 b_{2} \log \mathrm{EBW}\right) \\
\frac{d \mathrm{~L}}{d \mathrm{EBW}} & =\frac{d \mathrm{~L} / d t}{d \mathrm{EBW} / d t}=\frac{l}{\mathrm{EBWG}} \\
l & =\frac{\mathrm{L}}{\mathrm{EBW}}\left(b_{1}+2 b_{2} \log \mathrm{EBW}\right) \mathrm{EBWG}
\end{aligned}
$$

From eq B (Appendix 1)

$$
\begin{aligned}
p & =a_{o} a_{1}(\mathrm{EBWG}-l) \mathrm{FFM}^{\left(a_{1}-1\right)} \\
e & =5.48 p+9.37 l
\end{aligned}
$$

\section{Appendix 3}

\section{Calculation of body gain composition according to growth rate}

The daily lipid deposition $(l ; \mathrm{kg} /$ day) varies with growth rate (EBWG; $\mathrm{kg} /$ day) according to equation $D$ (Appendix 1).

$l=u \mathrm{EBWG}^{v}$

$v=1.78$ (Appendix 1)

$u=l_{o} /\left(\mathrm{EBWG}_{o}\right)^{v}$

$l_{o}$ is the lipid deposition of ad libitum fed animals with a reference growth rate EBWG (see Appendix 2)

$$
l_{o}=\frac{\operatorname{EXP}\left(b_{o}+b_{1} \log \mathrm{EBW}+b_{2}(\log \mathrm{EBW})^{2}\right)}{\mathrm{EBW}}\left(b_{1}+b_{2} \log \mathrm{EBW}\right) \mathrm{EBWG}_{\mathrm{o}}
$$

The protein and energy deposition are calculated in the same way as in Appendix 1 .

$p=a_{0} a_{1}(\mathrm{EBWG}-l) \mathrm{FFM}$

$e=5.48 p+9.37 l$ 


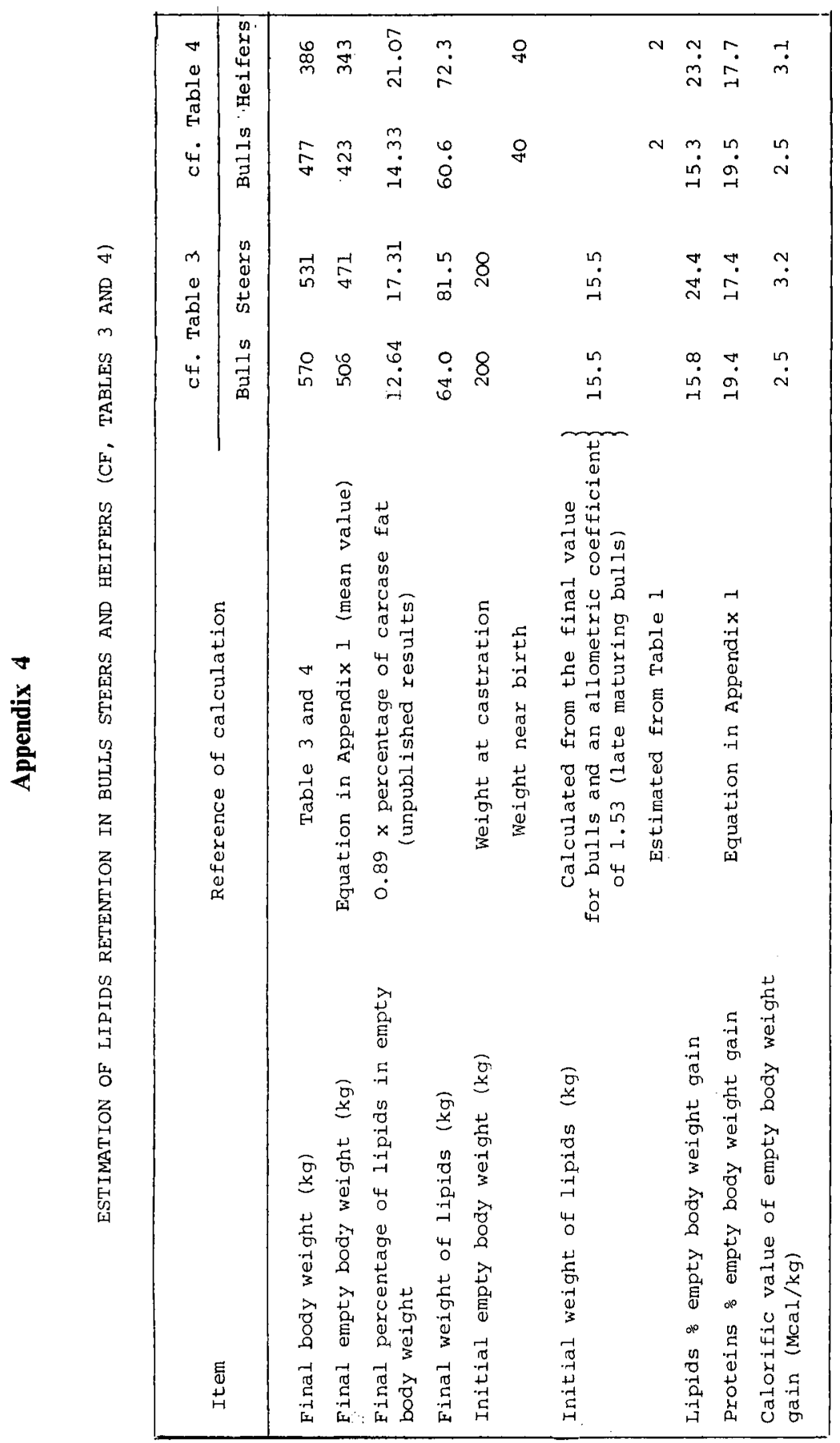




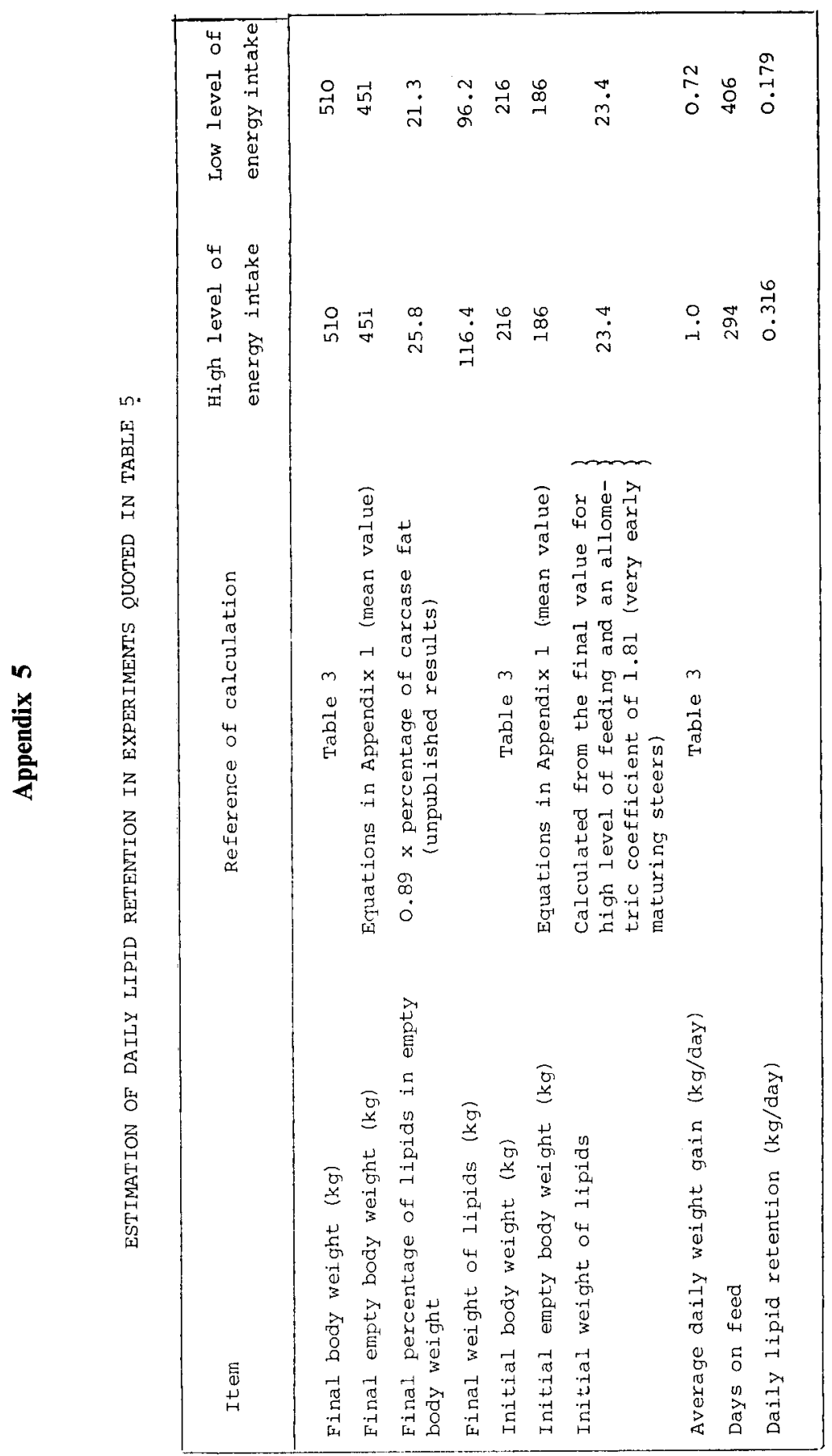




\section{Discussion}

\section{Chair : H. BICKEL (Switzerland)}

D. LANari (Italy). - In collecting your data did you consider two-phase feeding for beef animals?

J. Robelin (France). - No, I began with the more simple data. There were several feeding levels but only one feeding level for each group of animals during the whole period. I think it would be more difficult to interpret the results with variation in feeding level and so on.

A.J.H. VAN Es (The Netherlands). - I have a theoretical question : if you had expressed your results as a percentage of mature body weight, you would then have the sexes, breeds, genotypes and so on, coming together. Could you explain everything in terms of growth being somewhat more rapid in one type of animal than another?

J. Robelin. - There are two answers to that question. The first one is partly a joke. If I had expressed the results in terms of percentage of mature weight, I am sure that many people in this room would have asked me what was my reference for maturity. Also, if I had expressed the results in terms of mature weight there would still be differences between breeds. I can give you two examples. The first is the difference between Limousin bulls, which are very late in maturing in terms of lipid deposition, and Friesian bulls which are early maturing as far as lipid deposition is concerned. The difference in mature weight between these two breeds is very small, perhaps $950 \mathrm{~kg}$ for Friesian bulls and $1050 \mathrm{~kg}$ for Limousin. It is not certain that there is truly a difference. It is possible to remove the effect of breed in the case of maximum protein accretion. If you relate the maximum protein accretion of animals in terms of percentage of protein weight, what somebody called "rate of protein accretion", against body weight percentage of mature weight, you find practically every kind of cattle on the same curve which is a decreasing relative rate of protein accretion. However, in the case of lipid accretion, differences still remain when you compare the animals on the basis of the same percentage of mature weight. Just last year we planned an experiment with Charolais and Friesian bulls slaughtered at approximately the same percentage of mature weight. At the same percentage of mature weight, there still remain differences between Charolais and Friesian.

A.J.H. Van Es. - Could that last aspect be due to genetic differences in volontary intake because that would explain the higher fat deposition.

J. Robelin. - In the particular case of Friesian and Charolais it is quite probable.

H. BICKel (Switzerland). - I believe that a good estimation of mature weight is quite important. I wonder whether anyone in the audience would care to comment on whether, in fact, it is so difficult. There are several models for this.

J. Robelin. - If you are thinking in terms of growth curves models, one possibility is the Gompertz curve. However, your estimate of extrapolated weight depends mainly on the shape of the curve during the experimental period when you are never quite certain that you do not have outside effects.

A.J.H. VAN Es. - Would not the average weight of mature breeding animals, bulls used for artificial insemination, be a good measurement of mature body weight ?

J. Robelin. - It is probably higher than the mean of the population; it may be 10 or 20 per cent higher, I don't know.

H. BICKeL. - I believe you need independent data of the weight of different animals in the whole population, rather than dependent, because statistically, if you have dependent weights of the same animals the growth curves will not be correct. 
G. Alderman $(U K)$. - If it is convenient at this point, this is by way of being a hobby horse of mine, I would look at this matter of prediction of the composition of body gains from a different angle*.

J. RobELIN. - I think that is another point of view of the variation of body composition but it is not an opposite view. You can take the relationship between water and lipid to make your calculations or the relationship between protein and fat free mass. You will find approximately the same variations in the whole body composition. Nevertheless, I think the two kinds of equation should be used in the two kinds of situations. I believe that the relationship between protein and fat free mass is better to express the evaluation of body composition with weight, and I believe that the relationship between lipid and water is better to express the variation of body composition at the same weight for different levels of feeding. Do you agree ?

G. Alderman. - Yes, I would agree with you there. In fact, this is a different problem. You were trying to describe the composition if you knew the empty body gain ; I am starting from a different position. I do not know empty body gain ; I know energy retention ; I am hopeful that I might know protein deposition. If I know those two, can I predict the achieved empty body gain ? That is the practical nutritionist's problem. Can I predict what the animal will do, not can I describe what it did do. But they are opposite sides of the same problem.

H. Bickel. - What we want is to predict the daily weight gain. We can do that by the fat component on the one hand, by the protein on the other, and then by the difference between empty body weight gain and full body weight gain. What Dr. Robelin has pointed out means that the correlation between fat free body weight gain and protein is not a constant. I think this is the crux of the matter because a lot of different models use a constant between fat free body weight gain and protein ; this is not correct.

G. Alderman. - I should just add one comment on my presentation. It is only a Mark I model, it has said nothing about the ash content of the gain but we all know it is only about 5 per cent and you could easily put that into the model.

H. Bickel. - Has anyone any comments on the question of how the nutritionists could co-operate to a greater degree with the breeding people ?

\section{A. Neimann-Sørensen (Denmark). - Or vice versa !}

G. Alderman. - I would like to ask our French colleagues a question. The data you have on Friesian bulls show very low energy values for the gain of about $10 \mathrm{MJ} / \mathrm{kg}$. We are very puzzled about this because we would suggest that for our diets and our type of Friesian bull we would only decrease energy values by about 15 per cent from value of $20-22 \mathrm{MJ}$ for steers, which leaves a big gap between us. It makes me wonder whether you have a dietary effect, the way you feed your bulls.

J. Robelin. - Actually they are not "my" bulls. All the data is tabulated in Table 1 of the paper and it is from a wide variety of sources.

G. Alderman. - The figure I quoted of $10 \mathrm{MJ} / \mathrm{kg}$ is from your earlier paper by Geay and Robelin. I am curious as to why there is this big difference in the energy value of Friesian bulls between what you can do here and what we do in England.

Y. GeAY (France). - In this special case it is probably due to the fact that our Friesian bulls do not receive so high a percentage of concentrates as in your conditions.

G. Alderman. - That was my point; have we a dietary effect here ? If we have a dietary effect we really need to enquire into it. You implied that it was an all-forage diet ; if so, what was the forage ?

Y. GEAY. - During the first part of the feeding period the forage was hay, representing 60 per cent of the diet. At the end of the fattening period it represented 20 per cent of the diet. The animals were also fed this high concentrate diet at the second time of the fattening period.

(*) See Appendix to Discussion. 
G. Alderman. - And the nature of the protein supplements you used ?

Y. GEAY. - In percentage of the crude protein content it was about 13 per cent during the second part of the fattening period.

G. Alderman. - Yes, but were you using heat treated proteins, formaldehyde treated proteins, soyabeans, or what?

Y. GEAY. - Soyabeans.

G. Alderman. - Forgive me for pursuing this but $I$ wish to refer to trials which have been made in the UK by the Meat and Livestock Commission, where they used a diet fed ad libitum to bulls, of barley and high temperature dried grass. The rates of gain achieved were in excess of $1.5 \mathrm{~kg} / \mathrm{day}$ which were really quite outstanding when they were first achieved. This could have been due to a rise in protein deposition of these bulls to levels not previously recorded in the UK. I have no way of proving this ; it is merely a suspicion.

Y. GEAY. - There is another point we have to consider. Even in France if we want to compare the different types of Friesian, we will observe large variations in body composition, even on the same diet.

G. Alderman. - That too, I suspected.

H. Bickel. - Well, it is quite astonishing to have only this $10 \mathrm{MJ} / \mathrm{kg}$ body liveweight gain - it is very low.

K. RoHR (Federal Republic of Germany). - I have some figures in connection with what Mr. Alderman said.

\begin{tabular}{|c|c|c|c|c|}
\hline$\underset{(\mathrm{kg})}{\mathrm{W}}$ & $\frac{\Delta \mathrm{EGB}}{\Delta} \times 100$ & & EGB $(g)$ & day \\
\hline 200 & 82 & 4.6 & $\Delta p+0.8$ & $\Delta f+25$ \\
\hline 300 & 88 & 3.95 & $\Delta p+1.0$ & $\Delta f+25$ \\
\hline 400 & 95 & 3.91 & $\Delta p+1.0$ & $\Delta f+53$ \\
\hline 500 & 97 & 3.8 & $\Delta p+0.95$ & $\Delta f+55$ \\
\hline
\end{tabular}

There is a liveweight range from $200-500 \mathrm{~kg}$ and the empty body gain (EBG) as a percentage of liveweight gain increases from 82 to 97 per cent - this is an important point. Then there is the empty body gain in $\mathrm{g} / \mathrm{day}$ as related to protein deposition, fat deposition, and a certain constant which should be the ash content.

H. BICKEL. - This shows us exactly what Dr. Robelin has given us for the differences in water content of fat free body weight gain.

A.J.H. VAN Es. - With Friesian bulls we very often find that those animals which grow most rapidly eat the least amount of food. The animals that eat a lot, grow slowly. I think that is because of differences in genotype. Some are much earlier maturing than others.

H.J. OsLage (Federal Republic of Germany). - I have just one comment in connection with Mr. Alderman's question. If we speak of fat deposition under almost ad libitum feeding conditions, we should define the kind of ration, because there can be quite wide variations in energy intake. 